http://dx.doi.org/10.7833/117-1-1369

\title{
HORIZONS IN TRANSFORMATIONAL DEVELOPMENT AND TRANSNATIONAL MIGRATION: DOES HOPE MATTER?
}

\author{
Barnabé Anzuruni Msabah \\ Department of Practical Theology and Missiology \\ Stellenbosch University \\ School of Theology \\ Pan Africa Christian University \\ Nairobi, Kenya
}

\begin{abstract}
There is growing interest in the wellbeing of refugees and particularly the strategies they employ in their quest for improved livelihoods. This article reports on a recent study on the dynamics of the refugee phenomenon. It focuses largely on the longterm livelihood strategies that refugee migrants bring into play so as to earn their living and improve their wellbeing amid sheer vulnerability. The study reveals that the majority of African refugees in Cape Town have shifted from short-term survival mechanisms such as the dependence on relief from churches, faith-based organisations, mosques, etc., to long-term strategies. The article concludes by exploring the concept of development as hope in action. Here, it is established that although a considerable number of refugees leave their home countries with a certain level of uncertainty concerning their survival in the hosting country, they use their hope as a resource to improve their livelihoods.
\end{abstract}

Key Words: Transformational Development; Practical Theology; Hope in Action; Refugee Phenomenon; Survival Mechanism

\section{Introduction}

While every refugee's story is different and their anguish personal, they all share a common thread of uncommon courage: the courage not only to survive, but to persevere and rebuild their shattered lives.

- António Guterres (Secretary-General of the United Nations)

I urge you to celebrate the extraordinary courage and contributions of refugees past and present.

- Kofi Annan (Former Secretary-General of the United Nations, 1997-2006)

These words of high-profile United Nations (UN) personalities provide pointers to the courage of refugees and their resolve to survive in the hosting country. They are also indicative of migratory movements bred by serious violations of human rights, internal conflicts and various other forms of violence in most African countries. In view of this, Ferris (1993:68) notes that "historically, people have always sought to move when they 
were unable to survive" while Harzig, Hoerder and Gabaccia (2009:8) suggest that "the history of humanity is a history of migration".

Baggio (2005:1) indicates that "migration, like any other human phenomenon, represents a worthy subject for a serious theological reflection". This is because the phenomenon is long-established in the history of humanity. Nevertheless, it could be argued that globalisation, particularly improved communication and transportation systems, has made it easier today. Unlike other migrants, refugees are forced to leave their countries; that is, they do not choose to do so. Jacobsen (2002:579) notes that most receiving countries seek to prevent the arrival of refugees and limit the granting of asylum. South Africa is no exception. In South Africa, refugees are considered to be among the main contributors to the rising crime rates in the country, so that they are considered as adding no value to the country's economic growth (cf. Buscher, 2011:18; Belvedere, 2007:58).

As it were, majority of refugees leave their countries uncertain of their survival in South Africa but they continue to put their hope into action to pursue and improve their livelihoods. Nevertheless, the UNHCR's programme for livelihood and self-reliance preaches the message of "helping refugees help themselves" to reduce their dependency on and the cost of humanitarian assistance (UNHCR, 2012:6). In this regard, there is growing interest in the wellbeing of refugees and particularly the strategies they utilise in their quest for improved livelihoods. There is, however, a dearth of literature on the refugee phenomenon from the perspective of social theology worldwide and here South Africa is no exception. Even fewer are the studies on the socio-economic coping mechanisms that refugees themselves employ to improve their own livelihoods. This article addresses that knowledge gap by analysing the strategies that refugees in Cape Town employ in order to keep going despite the circumstances in which they find themselves.

Against this background, the two-fold question this article attempts to answer is - what are the strategies refugees in Cape Town employ to survive, and what role do they play in the country's economic growth? This article will answer the above question, which is, on the one hand, to analyse refugees' paradigm shift from survival mechanisms to livelihood strategies and, on the other, to present qualitative evidence of the role hope plays in refugees' lives and how it contributes in improving their wellbeing. This article is of great significance in that it has a potential to impact positively on the Southern African migration discourse and faith communities by introducing a ministry that could help to enhance the livelihoods of refugees.

\section{Methodological Considerations}

Considering the need for rich data and thick description of lived experiences, the study needed an in-depth exploration. A qualitative approach was adopted to allow detailed descriptions of the phenomenon under investigation during data gathering. For this research, data was collected through a triangulation of methods, namely, focus groups discussions (FGDs), key informants interviews (KIIs), a short survey with a very small population, and document analysis.

Besides, this research was designed and conducted within the frames and following the principles of a case study because its nature required exploration of refugees' lived experiences. The data of this research was collected from adult refugees and a few 'nonrefugee' role players who had relevant information about refugees, such as social workers and healthcare providers. First, data was collected using the method of document analysis. Here, existing textual materials were used not to only review literature but also as sources of information. As instruments for literature review, textual documents helped with the $a$ 
priori familiarisation of the body of knowledge and with the theories or principles behind the phenomenon under study. As sources of information, textual documents were objects of investigation. In this way, the contents of relevant documents, in an attempt to find and gather appropriate data for the research, were analysed critically.

In addition to the data collected from the existing written materials, data was also collected from participants using three different methods, namely, key informants interviews (KII, i.e. one-on-one interviews with refugees), focus groups discussions (FGDs, i.e. discussions with the members of the refugee community) and a short survey (i.e. distribution of a semi-structured questionnaire to a few role players - these are South African citizens who work for or with refugees. They were eligible on the basis of their active involvement with refugees). In other words, the FGDs and KIIs were conducted qualitatively with refugees while the short survey was done with 'non-refugees' - those who work with or for refugees in various sectors. The questionnaire for this short survey was designed quantitatively.

The sample was chosen by triangulating two non-probabilistic sampling methods: purposive sampling and snowball sampling. The sample size as initially proposed was 30; however, having reached saturation, data was finally collected from 20 participants. All the selected participants were above 18 years old. These were divided into various age categories. In an attempt to achieve the best results in this research, the best features of traditional qualitative content analysis method or 'manual method' and of CAQDAS (Computer Assisted Qualitative Data Analysis Software) were used during the process of data analysis. It was vital to recognise the value of both, and to triangulate them during the analysis and management of data for this research. In this way, my preferred manual method was content analysis and ATLAS.ti was the preferred CAQDAS tool.

Finally, this article studies the narratives of hope as expressed by refugees in order to establish them as active partners in the development equation. It also aims at ensuring that they are not ignored when issues concerning their empowerment are discussed. Thus, an explicit aim of this article is investigating the relationship between hope and empowerment in an attempt to instil a hope in action consciousness and raise theological awareness of the refugee phenomenon, so that refugee migrants can find renewed hope for improved wellbeing amid their seemingly deplorable conditions of life.

In view of the above, the following guiding objectives had to be met:

a. To identify the challenges that refugees face through their lived experiences

b. To situate hope as a resource for development in ministry to refugees

c. To determine the impact of the refugee phenomenon on the wellbeing of refugees

\section{Does Hope Matter in Development Discourse?}

Development is a "constant improvement of the wellbeing of the entire population and of all individuals" (UNGA, 1986). A human being is therefore the heart of development. In other words, to achieve sustainable development goals, development activities must focus on improving the wellbeing of people. Tamas (1999:7) describes development as 'a process in which people become more active agents in improving their circumstances'. Thus, a human is both an active participant and a beneficiary of development activities. Development which is not aimed at improving the wellbeing of a human is no development.

A human consists of body, soul and mind, representing the physical (or material), the spiritual and the emotional aspects of a person respectively. When these three aspects of the self are in balance, there is holistic wellbeing. Thus, development needs to improve not 
only the material, but also the emotional and spiritual wellbeing of a person. This is what constitutes holistic development. The failure to include the emotional and the spiritual aspects of the self in the development equation, therefore, reduces the effectiveness of development research and interventions, and deprives any development activity of its vitality and/or sustainability (see Carbonnier, 2012:1; Beek, 2000:31; Tamas, 1999:7).

The common assumption is that the spiritual aspect of the self is the exclusive focus of faith. The basis of such a perception is the premise that only rationality (thus, the material or the emotional, and not the spiritual) is a human tool for assembling available evidence (empirical or conceptual) and for assessing it deductively or inductively (see Clark, 2004). However, reason often falls short of making sense of the realities of the world, and faith fills the gap. Thus, faith and reason are complementary and not contradictory. Reason properly used and faith properly understood can never beget competing claims (Swindal, 2001). The contention here is that all fields of research are meant to address the issues affecting the whole person to ensure holistic wellbeing.

Most researchers in religion and development (see for example Carbonnier, 2012:1; Marshall, 2001:339; Beek, 2000:36; Tamas, 1999:7) note that faith and/or spirituality remain(s) under-represented, marginal or ignored in development theory and practice. They also indicate that debates on the role of faith in the development discourse are on-going due to the global resurgence of religion. As it were, the secular-religious dichotomy gives rise to reluctance among academics and development agencies particularly on the integration of religion into mainstream development approaches (Carbonnier, 2012:1). Their reluctance is based somewhat on the meta-theoretical hypothesis of Auguste Comte's positivism, which asserts that the quest for truth and meaning are a sole prerogative of scientific investigation (Copleston, 1972:27). In the positivist school of thought, scientific knowledge is presumed to be the only authentic and valid knowledge because it allows verification of evidence and, therefore, gives cognitive prestige to science.

As a science closely linked to matters of faith, theology is not only concerned with 'spiritual' matters. It deals with all the aspects of human experience, including the physical and the emotional. Theology is therefore not 'a development taboo' (Beek, 2000:31). Rather, it links the secular and the religious in order to bring the material, emotional and spiritual aspects of the self to a deeper reflection of the realities of the world, which include the widespread refugee phenomenon with its subsequent challenges. Beneath such challenges lies the 'purgatory of asylum application' (Sutton, et al., 2011:34), by reason of which refugees' prospects of improved livelihoods are shattered. In this context, it could be argued that faith provides 'a different lens on development debates', to borrow the words of Marshall (2001:339), through which the theory of hope is best understood and its practice valued. With this 'different lens', the practice of transformational development is also viewed differently.

This explains why the church needs to be on the side of refugees. However, to walk with the poor, the marginalised, the oppressed, etc. is not always easy. As Hampson (2010:4) indicates, "to be identified with the victims means taking the side of the poor, and therefore against those who exploit or those who misuse their power". Given the fact that the church has chosen to side with the poor, it suffices to say that it has to side with refugees as well. In other words, "the church has announced its preferential option for the poor" as Jesus did, it also has to give refugees preferential treatment (Hampson, 2010:4). It is in this regard that theology addresses matters pertaining to the refugee phenomenon although when discussing issues of migration, theology is rarely mentioned. This observation is also made by Groody (2009:640) when he affirms that theology is almost 
never mentioned in major works discussing migration studies. Nevertheless, as he further indicates, "migration issues are so complex and far-reaching that understanding them demands a broad range of interdisciplinary research" (Groody, 2009:641), which is the approach this article has taken. This explains why Hampson (2007:3) says:

We live in a world that has so many contradictions - greater wealth than ever before in human history, yet more poverty and inequality; instant global communications, yet increased fear of outsiders and the stranger; more goods, services and money passing across the world, but greater restrictions on movement of labour, in spite of the modern economy's need for a more mobile supply of workers.

Indeed, the society has fear of strangers and outsiders, including refugees. This is very evident in the South African context and the findings of this research have proven this. It is a contradiction because greater wealth is found in the country but many, refugees included, live in abject poverty. This explains why they strive to make their lives better despite the many challenges they face.

\section{Ordinary People with Extraordinary Challenges}

The history of migration is not new. As Groody (2009:638) puts it, "migration has been part of human history since its origins". However, despite its long establishment "due to widespread changes precipitated by globalisation, [today] more people are migrating than ever before" (Groody 2009:638). The refugee phenomenon is a form of migration, although a forced one. In South Africa refugees enjoy the freedom of movement and are entitled to various legal rights but the feeling of vulnerability among them is increasingly high, resulting in compromised wellbeing and dignity (Buscher, 2011:21; Sutton, et al., 2011:31; Belvedere, 2007:59). They are often considered as parasites that deprive the local citizenry from enjoying the fruits of their struggle for freedom; as people who exhaust the country's resources and who 'should not be in South Africa in the first place' (Belvedere, 2007:58). Such sentiments make refugees live in renewed fear of xenophobic attacks resulting from intolerance.

Refugees are ordinary people going through extraordinary challenges - and this increases their vulnerability. Yet, even in the face of such challenges, refugees are known to be courageous, with a strong desire and determination to rise above their day-to-day hurdles. They strive to thrive in spite of the insurmountable odds against them. This is why Hampson $(2010: 9,10)$ finds that "[w] hen people feel forced to move to find alternative livelihoods, the governments of their home countries at best ignore the situation, at worst promote the move in the hope of remittances, whilst the receiving countries routinely criminalise such migrants, or consign them to a twilight world where they are neither seen nor heard". In this vein, it could be argued that the South African Department of Home Affairs (DHA) adds to refugees' vulnerability owing to the many irregularities regarding their documentation. For example, asylum seekers are told to bring 'any proof of identification from [their] country of origin' (DHA, 2013). It is also the case that most asylum applications are rejected by the Refugee Status Determination Officer (RSDO) on the basis that the applicants had not left their home countries owing to persecution; they came to South Africa in search of a better life. In that regard, they do not qualify for refugee status.

According to the 2012/2013 DHA's annual report (covering the period between April 1, 2012 and March 31, 2013), a total of 78142 applications for asylum were received. Of these, 36657 applications were rejected on the basis that they were 'manifestly unfounded, abusive or fraudulent'; a further 24520 were deemed 'unfounded' and rejected on that basis; only 3908 claims were approved and applicants granted asylum (DHA, 2013:90). 
Statistically, this implies that only 1 out of every 20 applications received was approved in 2012. It provides pointers to the claims of this respondent from Burundi who said that 'living in South Africa is difficult because the local population doesn't like foreigners'. One can therefore postulate that such rejections not only increase cases of undocumented migrants in the country, but also solidify the likelihood for corruption because the fear of being rejected may make refugees bribe the officials in order to get the document and avoid arrest, detention and deportation.

As it can be deduced from the preceding discussion, humanitarian assistance is a shortterm strategy that allows refugees to rebuild their lives in the hosting country. Many refugees use the assistance they receive while they are still 'newcomers' both to establish themselves and rebuild their shattered lives and so become self-reliant. According to the UNHCR (2011:15), self-reliance is 'the social and economic ability of an individual, household or community to meet basic needs in a sustainable manner and with dignity'. Therefore, being self-reliant improves and strengthens refugees' livelihoods, on the one hand, and reduces their vulnerability and dependence on humanitarian assistance, on the other. In their quest for improved livelyhoods, refugees accept work for insufficient payment as they often struggle to find jobs that could earn them sufficient money for survival. Quality livelihoods are essential for the emotional and socio-economic wellbeing of refugees. Thus, protecting refugees is concomitant to ensuring their livelihoods.

\section{The Quest for a New Identity: Alternatives to Short-Term Survival Mechanisms}

It should be noted that "[r]efugees and asylum seekers often travel to other countries in the company of others who have different, non-protection needs" (Hampson, 2010:10). In view of this, Lee (2010) posits that "migration involves changes in one's identity". This is the reason why most refugees in Cape Town do not want to return to their home countries, regardless of their living conditions and bad treatment they endure in the country. On the one hand, it is due to the life-threatening situations in their respective countries of origin and, on the other, it is because the hope of improving their livelihoods is higher in the host country. The church therefore needs to ensure that it accompanies refugees in their life of displacement, as Hampson (2010:11) observes. They thus put their hope into practice in order to achieve the hoped-for. This is why most refugees have more advantage in various aspects of their lives than they had in their home countries.

Brueggemann (2002:102) observes that 'hope is a distinctive mark of faith with dangerous and revolutionary social potential'. Here, Brueggemann implies that hope and faith are closely related. In this regard, refugees could be seen to practice hope as an alternative coping mechanism within the bounds of faith. Hryniewycz (2007:9) observes that the existential nature of hope is universal since it 'lives in all and is for all'. The community of faith ought to make known and defend the universal relevance of hope due to 'the common human experience of suffering and the dangers [of hopelessness] that it brings forth (Hryniewicz, 2007:68). The universality of hope makes it a quality of life for which no social group can claim its rightful ownership. Similarly, Bielawski (2007:284) finds that hope is experienced from within and reaches the depths of human soul, while Tinder (1999:13) argues that hope is a 'necessity', and therefore as necessary as light and air to human life. In this respect, 'no single tradition is the designated custodian of hope' (Brueggemann, 2002:102). With regard to the refugee phenomenon, one could argue that it is the presence of hope rather than the absence of it that keeps them going despite their increased vulnerability and undignified treatment in the hosting country. 
A growing number of people today succumb to despair because the current social system is not working. The community of faith can neither conform to the system nor withdraw from it. It has to rise to the occasion and provide it with a transforming framework that changes the status quo for the better and invite the social fabric to live in a new way - the way of faith, love and hope (see Tasker, 1962:536). In this regard, the community of faith helps the inclinations, the desires and the dreams of those in despair to be rooted anew in faith, love and hope. In this same vein, Moltmann (1971:49) observes that the more faith is in harmony with the groaning of people, the more love is in solidarity with them, and the more comprehensive the horizon of hope becomes. The 'groaning' people in Moltmann's observation includes refugees. One can therefore deduce that without hope the realities of the world could destroy love and shake the foundations of faith. Hope is a concomitant of faith. Thus, rootedness in faith determines the quality of hope and acts as a stimulus for pure love.

Identity is a crucial part of human existence. Yet, refugees often find themselves in a grey area awaiting a new identity. At the DHA, they are made to wait for extended periods of time before they are attended to. In this regard, Sutton et al. (2011:31) note that 'the more power, the less waiting; the less power, the more waiting'. In other words, waiting is associated with the powerless and 'not-waiting' with the powerful. Refugees are often made to wait in long queues (which often take days) expecting something, anything or nothing to happen. Their waiting, however, is not a waste of time or '[b]eing without [t]ime' as Günther Anders (1965:140) says of Samuel Beckett's (2006) play, Waiting for Godot, in which the two characters, Vladimir and Estragon, wait for a certain Godot who never comes. The two have no idea who this Godot is and do not even know what he wants. At the end of the day, when Godot does not show up, they take care of their disappointment by waiting for him the following day.

Like the waiting of Vladimir and Estragon, refugees' waiting involves disappointment, frustration and despair but, at the same time, it is fanned with a great sense of hope. It involves frustration and despair because of the fear that the long waiting might culminate in not reaching the front of the queue at the end of the day; and hope because the waiting is based on the longing for a new identity (see Sutton, et al. 2011:32). Thus, refugees' waiting is not a hopeless situation but rather a resilient waiting. This waiting in hope is a virtue that gives meaning to their existence. For them, waiting is a state of being and, therefore, a quality of life. Refugees live in a constant state of waiting: they are made to wait when in need of services from public offices; they wait for the situation in their respective countries to stabilise so that they might return home; they wait in long queues at the DHA for their documents to be processed; and they wait in hope for a better tomorrow. Thus, refugees' everyday life recounts a waiting story.

Like the resilience of Vladimir and Estragon, refugees keep waiting for their Godot despite the frustration and disappointment, driven by the assurance of faith, the embrace of love and the resilience of hope. Unlike Vladimir and Estragon whose waiting was fuelled by nothingness as they waited for Godot to come, refugees' waiting narrative is that of activity although coupled with a mixture of patience and impatience; belief and disbelief. Indeed as Moltmann (1971:49) observes, when belief and disbelief conflict, 'hope arises from patience and experience, and finally overcomes'. Thus, even in their waiting, refugees' hope for a better tomorrow triumphs over their doubt and impatience.

Waiting is associated with the virtue of patience. The word 'patience' in Greek (Hupomoné, cf. Strong \#5281) suggests bearing up a heavy load on the shoulder from the oppressor and abiding under such difficult circumstances when it is not possible to escape. 
Waiting is therefore concomitant to long-suffering (Brown \& Falkenroth, 1976:766). To quote Sutton, et al.'s (2011:31) words, 'it is hope that makes the powerless persevere and (...) ultimately makes waiting a phenomenon that is socially productive'. In agreement with Sutton, et al. (2011:36), it could be said that hope transforms refugees' waiting into a socially productive and resourceful weapon. It generates enough strength and breeds ability to wait patiently in spite of the fact that prevailing circumstances do not give any reason to do so or even though there are no rational grounds for it. They wait in 'active hope'. Thus, hopeful waiting is a strategy to pursue improved livelihoods for refugees' survival.

In this regard, one would concur with Keshgegian (2006:188) that 'we learn to hope anew when we practice hope'. It is indeed the case that refugees have a strong desire to be productive in order to take care of their families and pay the bills related to their livelihoods. They could be said to put their hope into practice to attain the hoped-for. Here, putting hope into action is what makes the powerless powerful and turns their waiting experience into a socially productive phenomenon. Botman (2001:70) observes that translating hope into action is 'a theological grounding to become meaningful' in this $21^{\text {st }}$ century. Thus, active hope is central to human living. It is a part of what it means to be human. The prevalence of hopelessness and despair, that is, the 'groaning of people' to borrow the words of Moltmann (1971:49), should therefore motivate the community of faith to get involved in the society in order to birth hope.

To nurse the frustrations and disappointments of the day, refugees seize every available opportunity to build up new hope for tomorrow. In their quest they rise above the dependence on relief and hand-outs from churches, faith-based organisations, mosques, etc. and, instead, engage in various trades, however insignificant, for their self-reliance. In this respect, hope is not abstract; it is visible through active involvement. It is a positive force with the potential to transform lives.

\section{Findings and Interpretation}

A respondent from the Democratic Republic of Congo explained his lived experiences thus: "Myself my asylum application have been rejected in 2006 then I did appeal 2008. Now I am still waiting final result till now". Although the waiting for his new identity takes longer than expected, the respondent keeps on waiting. It shows that for refugees, waiting is hopeful endurance and, therefore, a coping mechanism for survival. Various studies carried out in this domain (see Amit, 2013:32-33; Kiama \& Likule, 2013:34-35; Kane \& Kane, 2013:36) indicate that arresting and detaining refugees on the basis of documentation legitimises a variety of unlawful practices and gives rise to increased opportunities for bribery. Proper documentation is essential for refugees to settle and pursue improved livelihoods within the requirements of the law. Another respondent had this to say regarding the A4-sized permit given to refugees, which is often refused by most employers who require a green (i.e. South African) ID:

[The question of documentation] affects me negatively. Because with the A4 size temporary permit no job; even with the Status and ID; no professional job. That is why I do not do my professional job.

In the same vein, a respondent from Ethiopia said, on the issue of documentation and its consequential likelihood for corruption: 'It takes very long to get it and there is people they take the short cut to get it. I think that make it bad for the others'. As indicated by this respondent, some refugees decide to use a 'short cut' to acquire their documents in order to make a living and improve their livelihoods through legal means. It is noteworthy that the 
'short cut' he is referring to is monetary. These sentiments become more and more sensitive as another respondent who had been living in South Africa for more than 10 years. says: 'I have been trying to get an ID book since 2005 but they never responded without any reason'. Due to increased dissatisfaction on the question of documentation and service delivery by the DHA, a middle-aged Rwandan woman said:

The Home Affairs is the most horror place I never see; to go to Home Affairs and to stay illegal is just the same; we need international community to take care of us; not Home Affairs.

These sentiments echo the voices of many respondents. They explain refugees' feeling of vulnerability and the undignified treatment attributable to the disservices of the DHA. Remarkably, it demands great courage (e.g. travelling by bus from Cape Town to Durban ${ }^{1}$ or back to Musina [port of entry] to extend one's permit) in order to remain legally documented in South Africa. The challenges of documentation also make refugees depend on humanitarian assistance for survival rather than making a living through personal pursuits for livelihoods. It could be argued that such documentation challenges not only deprive refugees their human right to asylum and development but also contribute to the increase of criminal activities, in which some refugees engage for survival. Refugees benefit from humanitarian assistance mostly when they are still new in the country. This is because assistance is often reserved for the most vulnerable ones, the marginalised and the unaccompanied or orphaned children.

Studies carried out by various researchers (see Potts, 2011; Buscher, 2011:26; Jacobsen, 2002:585; Harrell-Bond, 2002) confirm that the contexts in which refugees pursue livelihoods are unsupportive and uncared for although they provide economic inputs in the form of skills and needed labour. This could be due to restrictive policies in most hosting countries. In South Africa until recently, it was illegal for asylum seekers to study, work or own businesses, and it is still illegal for both asylum seekers and refugees to own property or to access financial services such as loans. In this vein, a university student from the Democratic Republic of Congo said:

As a refugee I don't exercise all my rights; there are rights that a refugee cannot claim because he is not a citizen of the country; but a refugee student for instance should be allowed to apply for a loan to finance his studies.

Although refugees are now entitled to study and work, finding employment remains a great challenge because they compete for the jobs with the majority of the local population, who are in most cases prioritised for job openings (see Amit 2013; Belvedere 2007). This makes refugees' resilience fragile and their pursuit for improved livelihoods challenging. A Burundian respondent who believes he has 'unused talent' said the following:

I have been in South Africa for 12 years and in exile for 18 years. Have managed to get BSc, PGCE but have been no teaching positions because of the document I am using. Yes the country needs science teachers but fail to give a teaching post no matter how I managed to work on short contract for some months. I hold unused talent that the countries, the world need to profit from.

The sentiments provide pointers to the government's policy to prioritise civic services to the local population. The 'unused talent' of the respondent, however, could be an asset to the welfare and development of the country. A common misconception is that refugees are a dependent people surviving at the mercy of either the humanitarian organisations or the

That is approximately 2000 kilometres. 
generosity of the local community. However, the study has revealed that refugees exploit various available avenues to enhance their livelihoods. The factors that facilitate access to improved livelihoods and build resilience in refugees could be divided into three categories: internal factors, external factors and supernal factors. Internal factors involve personal qualities such as courage, strength of mind, determination and skills. External factors involve the support refugees receive from friends, relatives, faith communities and humanitarian organisations. Supernal factors include religious beliefs and spirituality (see Hutchinson \& Dorsett 2012:59-63). All these factors interact in helping refugees to improve their living conditions by pursuing productive livelihoods.

This study also revealed that most refugees are economically active and productive in their own way. The majority of refugees were found to be 'working' although most of them are self-employed in the informal sector. Those from the Great Lakes region were generally in the security line of work, car-guarding, repairing of appliances, hairdressing and barbing. Those from the Horn of Africa mostly owned or worked in retail supermarkets or Spaza shops $^{2}$. It emerges that the security/car-guarding 'industry' and restaurants (i.e. mostly Zimbabweans) are the leading 'employers' of refugees.

The study also found that most refugees in Cape Town have relatively strong societies, which increase their trust, ability to work together and help each other. Such societies are a social capital that multiplies their connections and gives them access to financial capital. They use the social media to get support from relatives or friends. The same applies when they want to send remittances to their home countries. There are many refugee-owned financial services in the city of Cape Town that facilitate money transfers abroad. These services provide an alternative to the South African banking system whose policies vis-àvis refugees are very restrictive. In some other cases, refugees make contributions to assist those in need, especially during bereavement or any tragedy. Refugees were also found to demonstrate enviable solidarity with the newcomers in their midst whom they accommodate from the time they arrive until they find something to earn them a living. Those who own businesses, such as Somalis, introduce the newcomers to the world of business without delay. One respondent asserted the following:

If South Africa was good country it suppose to assist refugees fully because we are paying tax and create job; imagine if you come to Bellville many shops of foreigner they employ many South African. And imagine apartheid time South African was refugee in all over Africa but they treat them nice until 1994.

The words of this respondent indicate that refugees are economically productive and have skills that could make them a useful asset to the hosting community if allowed to fully explore their potential. The livelihoods of migrants are linked to the acquisition of goods, services and cash. Unlike other migrants, however, refugees find little opportunity to increase their means of support or sources of revenue. They face realities that thwart their holistic wellbeing and prevent them from exploring various developmental avenues for self-empowerment.

Refugees' resolve to succeed is also demonstrated by the strength of their mind. Their hope for improved livelihoods and holistic wellbeing propels them to work harder in order to establish their presence in the hosting community. The hope of seeing their dignity restored is made concrete in the pursuit of and access to livelihood opportunities. They end up being their own bosses because finding a job is a challenge even to the local population. Even when salaried employment is not forthcoming, their financial burdens compel them to

2 In South Africa, a Spaza shop is a mini shop mostly found in townships. 
engage in some form of self-employment to preserve their dignity and economic independence.

Based on the findings, this research has established that (i) although most refugees in Cape Town struggled to attain an improved level of livelihood, migration has enhanced their socio-economic savoir-faire, which benefits the welfare and development of the country; (ii) the majority of refugees in Cape Town have shifted from short term survival mechanisms such as the dependence on relief from charity organisations to long-term strategies in the pursuit for improved livelihoods; (iii) and the strategies pursued by refugees for livelihoods make them agents of change and proponents of hope in action.

Furthermore, the findings have revealed that refugees are victims of circumstances that have inflicted neediness, hopelessness and misery upon them but they are capable people with various skills and expertise albeit without resources. Even though they are faced with challenges, refugees put their hope into action to increase the chances of improving their livelihoods. In this way, their resolve to succeed against the odds propels them to engage in various kinds of trades to earn a living. Thus they play a positive role in improving the living condition of many. Such resolve to improve their livelihoods is therefore a commitment to work successfully and reach a certain level of self-sufficiency, which would see them integrate into the mainstream South African society and become open to social change.

\section{Conclusion}

Although refugees are often portrayed as helpless people whose source of revenue depends on the benevolence of others, this research found that refugees are agents of change and contribute to the economic development of their hosting country. They have been shown in this research as people who have the ability to employ a whole range of coping mechanisms to ensure improved livelihoods. This they do not only for survival purposes but also for the purpose of giving their life meaning through dignified and sustainable means of support. In spite of the challenges they have to surmount on a daily basis, refugees' narratives express hope for a better tomorrow. For them, hope does indeed matter. This explains why refugees put their hope into action as a livelihood strategy by seizing every available opportunity to build up new hope for a better tomorrow. The research has pointed out that refugees in Cape Town rise above the dependence on relief and hand-outs from charitable organisations and, instead, engage in various trades, however insignificant, for sustenance. For them, development is about making use of hope as a resource by putting it into practice.

South Africa is now a constitutional democracy founded on internationally recognised values such as non-discrimination and human dignity. Human dignity, being one of the fundamental values of a human being, needs to be respected, defended and protected. Ferris (1993:66) points out that people leave their countries because they are either 'unable to survive or afraid to live there'. Her sentiments indicate that for some people, home might be the most dangerous place to live, and asylum could be their sole alternative. It is however the case that refugees strive for local integration into the mainstream South African society regardless of the discriminatory treatments they endure or the constant fear of looming xenophobic attacks. Some of them rely on short-term humanitarian aid due to restrictive policies of the hosting country, which limit them from exploring various other avenues for self-reliance.

This article has presented hope as a practical paradigm for transformational development and the actuation of this hope as necessary for improved wellbeing. Put into action, hope could rekindle the ambitions of the less-privileged in the community such as it has 
been shown here in the case of refugees living in Cape Town. Their coping mechanisms constitute an opportunity for new hope as it has been evidenced that they strive to rise beyond the satisfaction of basic needs for survival to the meeting of specific long-term goals. If managed properly, the refugee phenomenon presents an opportunity that could be capitalised upon to bring about the desired transformational development leading to a more productive economy in any refugee-hosting country. To be human entails being discontented with the ever-present predicaments of life that are increasingly causing despair in the world. It entails helping those in despair to hope anew. In this way, they will be empowered by their renewed hope. Attitudes towards transformational development should therefore be reflected in the efforts to empower the powerless and restore their dignity.

\section{BIBLIOGRAPHY}

Amit, R 2013. "Security Rhetoric and Detention in South Africa." M Couldrey, \& M Herson, (eds.). Forced Migration Review. 44:32-33.

Amit, R 2009.Vigneswaran D; Monson T \& Wachira GM. National Survey of the Refugee Reception and Status Determination System in South Africa. Wits University. Johannesburg: Forced Migration Studies Programme.

Anders, G 1965. "Being without Time: On Beckett's Play Waiting for Godot". In M Esslin (ed.), Samuel Beckett: A Collection of Critical Essays (pp. 140-151). New Jersey: Prentice-Hall Inc.

Baggio, F 2005. Theology of Migration. Cape Town: Scalabrini International Migration Institute.

Beckett, S 1965. Waiting for Godot (2nd ed.). Kent, Great Britain: Whitstable Litho Ltd.

Beek, KA 2000. "Spirituality: A Development Taboo." Development in Practice 10, $1: 31-43$

Belvedere, MF 2007. "Insiders but Outsiders: The Struggle for the Inclusion of Asylum Seekers and Refugees in South Africa." Refuge, 24, 1:57-70.

Bielawski, M 2007. "Thinking about Church with Hope: The Example of Waclaw Hryniewicz.” In W Hryniewicz, The Challenge of Our Hope (pp. 269-285). Washington: RVP.

Botman, RH 2001. "Hope as the Coming Reign of God.” In W Brueggemann (ed.), Hope for the World. London: Westminster John Knox Press.

Bourdeau, M 2013. Auguste Comte. EN Zalta, (ed.). Retrieved October 18, 2013, from The Standford Encyclopedia of Philosophy: <http://plato.stanford.edu/archives/win2013/entries/comte/>

Brown, C \& Falkenroth, U 1976. "Patience, Steadfastness, Endurance.” In C Brown (ed.), The New International Dictionary of New Testament Theology (pp. 764-765). London: Paternoster Press.

Brueggemann, W 2001. "Communities of Hope Midst Engines for Despair." In W Brueggemann (ed.), Hope for the World. London: Westminster John Knox Press.

Brueggemann, W 2002. "Hope.” In W Brueggemann, Reverbations of Faith: A Theological Handbook of Old Testament Themes (pp. 100-102). London: Westminster John Knox Press.

Buscher, D 2011. "New Approaches to Urban Refugee Livelihoods." Refuge 28, 2:17-29. Carbonnier, G 2012. Religion and Development: Reconsidering Secularism as the Norm. Boston: Leiden. 
Clark, J 2004. Religious Epistemology. Retrieved October 17, 2013, from Internet Encyclopedia of Philosophy: A Peer-Reviewed Academic Resource: http://www.iep.utm.edu/relig-ep/

Copleston, F 1972. Contemporary Philosophy: Studies of Logical Positivism and Existentialism. London: Continuum.

DHA: Department of Home Affairs 2013. Annual Report: 2012 -2013. Pretoria: Home Affairs.

DHA: Department of Home Affairs 2013. Refugee Status \& Asylum. Retrieved October 15, from Home Affairs: http://www.home-affairs.gov.za/index.php/refugee-status-asylum

Ferris, EG 1993. Beyond Borders: Refugees, Migrants and Human Rights in the Post-Cold War Era. Geneva: WCC.

Freire, P 1992. Pedagogy of Hope. New York: Continuum Publishing Company.

Fyodorov, N 2003. Philosophy of the Common Cause. In V Zenkovskij, History of Russian Philosophy (1st ed., p. 968). London: Routledge.

Groody, D 2009. "Crossing the Divide: Foundations of a Theology of Migration and Refugees." Theological Studies, 70(2):638-667.

Hampson, SJ 2009. Accompaniment - A New Way of being Present? Geneva: JRS.

Harrell-Bond, BE 2002. "Can Humanitarian Work with Refugees be Humane?" Human Rights Quarterly, Volume 24, Number 1:51-85.

Harzig, C, Hoerder, D \& Gabaccia, D 2009. What is Migration History? Cambridge: Polity Press.

Hryniewicz, W 2007. The Challenge of our Hope: Christian Faith in Dialogue. Washington: RVP.

Hutchinson, M \& Dorsett P 2012. "What does the Literature say about Resilience in the Refugee People?” Implications for Practice. Journal of Social Inclusion, 3, 2:55-78.

Jacobsen, K 2012. Refugee Livelihoods in Urban Areas: Identifying Program Opportunities. Boston, USA.: Feinstein International Center, Tufts University.

Kane, MC \& Kane, SF 2013. "A Last Resort in Cases of Wrongful Detention and Deportation in Africa." Forced Migration Review, 36.

Keshgegian, FA 2006. Time for Hope: Practices for Living in Today's World. London: Continuum Publishing Company.

Kiama, L \& Likule D 2013. "Detention in Kenya: Risks for Refugees and Asylum Seekers”. Forced Migration Review, 34-35.

Marshall, K 2001. "Development and Religion: A Different Lens on Development Debates." Peabody Journal of Education, 76, 3\&4 Global Issues in Education, 339-375.

Moltmann, J 1967. Theology of Hope. London: SCM Press Ltd.

Moltmann, J 1971. Hope and Planning. London: SCM Press Ltd.

Potts, D 2011. "Making a Livelihood in (and beyond) the African City: The Experience of Zimbabwe." AFRICA, 81, 04K588-605.

Rosenkranz, E 2013. Those People: Political Construction of Refugees and Asylum Seekers in South Africa. Lund: Lunds Universitet.

Roux, N 2009. Migration and Urbanization: Towards a 10-year Review of the Population Implementation in South Africa (1998-2008). Pretoria: Department of Social Development, RSA.

Sutton, R, Vigneswaran, D \& Wels H 2011. "Waiting in Liminal Space: Migrants' Queuing for Home Affairs in South Africa." Anthropology in South Africa, 34, 1\&2:30-37. 
Swindal, J 2001. Faith and Reason. Retrieved October 17, 2013, from Internet

Encyclopedia of Philosophy: A Peer-Reviewed Academic Resource:

http://www.iep.utm.edu/faith-re/

Tasker, RV 1962. “Hope.” In JD Douglas (ed.), The New Bible Dictionary (1st ed., pp. 535536). London: Inter-Varsity Press.

Tinder, G 1999. The Fabric of Hope: An Essay. Atlanta: Emory University.

UNGA: United Nations General Assembly 1986. Declaration on the Right to Development. (A/RES/41/128). New York, USA: United Nations. Retrieved October 9, 2013, from http://www.un.org/documents/ga/res/41/a41r128.htm

UNHCR 2011. Promoting Livelihoods and Self-Reliance: Operational Guidance on Refugee Protection and Solutions in Urban Areas. Geneva, Switzerland: UNHCR.

UNHCR 2012. Livelihood Programming in UNHCR: Operational Guidelines. Geneva, Switzerland: UNHCR. 